\title{
Sociology of a scandal: the emergence of 'FIFAgate'
}

\section{Emmanuel Bayle \& Hervé Rayner}

To cite this article: Emmanuel Bayle \& Hervé Rayner (2016): Sociology of a scandal: the emergence of 'FIFAgate', Soccer \& Society

To link to this article: http://dx.doi.org/10.1080/14660970.2016.1228591

\section{曲 Published online: 09 Sep 2016.}

Submit your article to this journal 전

Q View related articles ¿

View Crossmark data $\nearrow$ 


\title{
Sociology of a scandal: the emergence of 'FIFAgate'
}

\author{
Emmanuel Bayle ${ }^{\mathrm{a} *}$ and Hervé Rayner ${ }^{\mathrm{b}}$ \\ ${ }^{a}$ Institut of Sport Sciences (ISSUL), University of Lausanne, Lausanne, Switzerland; \\ ${ }^{b}$ Research Centre for Political Action (CRAPUL), University of Lausanne, Lausanne, \\ Switzerland
}

This article examines the social forces underlying FIFAgate. Why do corrupt practices, which are often highly consolidated or even institutionalized, suddenly become scandalous? What is a scandal? Why did FIFA fall into crisis in 2015 and not before? To answer these questions, it is necessary to look at the sequence of thrusts and parries between all the parties involved. Our analysis embraces the notion that social processes are based on relationships in order to provide insights into why and how denunciations can lead to long-tolerated corrupt practices suddenly becoming compromising enough to force an organization's leaders to implement measures that would have previously been unimaginable. We use multiple sources to examine the emergence of FIFAgate and the way FIFA overcame previous critical situations, describing how FIFA neutralized earlier allegations and developed a remarkable 'resilience' to scandal. Finally, we analyse the successive mobilizations whose domino effect led to the emergence of FIFAgate and the measures FIFA took to contain the scandal. Our research enabled us to draw up a new theoretical model for analysing corruption scandals.

\section{Introduction}

Christian Favre, journalist, radio news presenter: 'To conclude, does Sepp Blatter, as we are often told, does he run his FIFA honestly or not?'

Joël Robert, journalist, head of the sports desk: 'Well, you know, he runs it honestly because, logically and legally, there have been legal proceedings, but Blatter and FIFA have never been caught out. There are still proceedings under way. I tell you that Blatter will be re-elected very comfortably. He will keep going. He has been at FIFA for 30 years, president since ' 98 , but, clearly, if a corruption or some other sort of scandal breaks, well, in that case, Blatter will fall from his throne. But, at the moment, he is solidly seated on that throne.' (28 August 2014) ${ }^{1}$

This exchange between two journalists speaking live on Swiss public radio shows that suspicions of corruption within the Fédération Internationale de Football Association (FIFA) had already emerged before the 'FIFAgate' scandal broke in 2015. More than just rumours, leaks by whistleblowers had led to explicit allegations by 'critical voices' (Andrew Jennings, Change FIFA, Transparency International, Play the Game) and police enquiries. In fact, for many years, media investigations, notably by the BBC, The Guardian and The Sunday Times, had uncovered evidence of corrupt practices within FIFA, although they had never managed to directly incriminate the organisation's Swiss president, Sepp Blatter. The ability of the world's most

*Corresponding author. Email: Emmanuel.bayle@unil.ch 
powerful sports institution, alongside the International Olympic Committee (IOC), to neutralize allegations of corruption contributed to the widely shared idea, even among Blatter's opponents, that its leader ('the unbudgeable') would always manage to dodge the accusations. This reputation of invincibility made it more difficult to denounce goings on at FIFA and added to Blatter's symbolic capital. ${ }^{2}$ However, like all organizations, FIFA was vulnerable to changes in its relations with other institutions (sporting, political, economic, legal, media), and 'FIFAgate', like everyother scandal ${ }^{3}$, was the result of a sudden reconfiguration of these intra- and inter-institutional relations.

The present article examines the social forces underlying FIFAgate. What is a scandal? Why do corrupt practices, which are often highly consolidated or even institutionalized, suddenly become scandalous? Why did FIFA fall into crisis in 2015 and not before? In order to answer these questions it is necessary to look at the sequence of thrusts and parries between the numerous parties involved, including sports executives, public relations companies, sports marketing agencies, politicians, journalists, magistrates, lawyers and multinational sponsors. By embracing the notion that social processes are based on relationships, our model provides insights into why and how denunciations can lead to long-tolerated corrupt practices suddenly becoming compromising enough to force an organization's leaders to implement measures that would have previously been unimaginable (resignations, desertions, revisions to rules). We begin by discussing the limitations of most previous social science researches into corruption, which have tended to focus on transgressions while paying little attention to a factor we believe to be crucial, that is the extremely variable cost of denunciations. We then describe our relational approach to analysing scandals and the methods and sources used in our case study. Finally, we look at the way FIFA overcame previous critical situations and examine the successive mobilizations whose domino effect led to the emergence of FIFAgate, together with the measures FIFA took to contain the most serious scandal in its history.

\section{Corruption as an object: the state of the art}

Corruption has been a research object in the social sciences for many years, giving rise to numerous studies ${ }^{4}$ based on a variety of concepts, methods, disciplines, sources and fields of observation. Nevertheless, analyses of political corruption continue to dominate this vast literature. ${ }^{5}$ Although the tortuous dimension of these shadowy practices makes observation, especially participant observation, difficult there is no lack of sources. Whether information is provided by administrative, judicial, law enforcement or journalistic sources, it is likely to contain biases that have to be taken into account, as such information is rarely collected scientifically. Furthermore, much of the research into corruption has been carried out at the instigation of powerful international organizations (IMF, World Bank, UNO, OECD, Council of Europe and the Group of States Against Corruption - GRECO) or NGOs (Transparency International). This has greatly influenced the focus of studies, which have tended to concentrate on practical issues (how to measure and fight corruption), thereby impinging on the objectification required for scientific enquiry. For example, since the 1960s, numerous researchers have examined the effects of corruption on development in third world countries. Some consider corruption to be a necessary step towards economic growth and the emergence of 'civil society', 
whereas others see it as a vicious circle, especially for public confidence. Outside the developing world, corruption is often analysed in the light of its supposed influence on social inequalities. ${ }^{6}$ The resulting focus on costs (economic, political, social) within comparative quantitative studies raises the risk of decontextualization. In the wake of the corruption indices produced by Transparency International, researchers are increasingly using surveys and questionnaires to examine 'ordinary' citizens' perceptions of small-scale and large-scale corruption. ${ }^{7}$ Here, corruption is seen as contributing to people's distrust of both government authorities and companies.

These normative tendencies are emphasized even more in research focusing on sport $^{8}$, which tends to be carried out from a problem-solving perspective. This is why revelations by investigative journalists ${ }^{9}$ and $\mathrm{NGOs}^{10}$ have been followed by intense research into problems such as hooliganism, racism, doping, match-fixing and corruption. For example, Masters ${ }^{11}$ argues that organized sport has entered a fifth evolutionary phase - criminalization. In this latest phase, public policy needs to grapple with what constitutes corruption in what has historically been a private market. According to Becker ${ }^{12}$, FIFA can only restore public confidence by setting up a world anti-corruption agency in conjunction with other sport governing bodies. Research in the field of sports management, much of which has focussed on FIFA and the IOC, has identified links between corruption and deficiencies in the control and accountability of international sports organizations ${ }^{13}$, as well as looking at the possible positive effects of social responsibility. ${ }^{14}$ With these tendencies among scholars (problem-solving, focus on transgressions and/or on media, i.e. media-centrism), sociology of sporting scandals is in limbo. ${ }^{15}$

Research into corruption, whether in sport or other sectors, has furthered understanding of the phenomenon, but the feasibility of denouncing corruption is an issue that is never addressed. Nevertheless, we see this as a fundamental point in understanding the mechanisms underlying corruption scandals: the practices (misappropriation of funds, bribery, breach of trust, fraudulent use of property, etc.) covered by this polysemous word only become scandalous when the people who see them as scandalous manage to gain support in several social spheres. Despite the common understanding of the word, and in contrast to most scientific papers on corruption, which usually confound the committing of scandalous acts with scandal ${ }^{16}$, it takes much more than revelations of wrongdoing to create a scandal and thereby strip the people and institutions accused of these acts of their legitimacy - indignation, just like denunciation, mobilization or sanctions, cannot be taken for granted.

\section{A model for analysing scandals}

Although scandals are frequent events in contemporary societies, they remain ill defined by social scientists, most of who consider them to be controversies centred round wrongdoings by well-known figures, minor affairs inflated by the media. Due to the rarity of specific studies ${ }^{17}$ or summaries ${ }^{18}$, and the fact that both protagonists and observers primarily see scandals as the revelation of transgressions, little is known about the phenomenon. Consequently, academics' attention continues to be monopolized by the misdeeds committed, to the detriment of the process that allowed the scandal to break.

Scandals occur when the people challenging another person's or organization's probity are supported by simultaneous 'multisectoral mobilisations', that is 
mobilizations that take place in and between several social sectors. ${ }^{19}$ A scandal can occur even if the 'scandalous facts' are unfounded (e.g. due to false accusations), but most 'scandalous facts' (such as paying bribes) fail to lead to scandals. Consequently, it would be misleading to equate scandal with transgression. Multisectoral mobilizations are essential if a dispute between a few individuals is to turn into a scandal, but they are rare because they are subject to the difficulties facing any collective action, which are exacerbated when the practices being challenged are protected by strong collusions within and between powerful institutions. Such collusions are not necessarily illegal or explicit. Often, they are based on the shared expectations of leaders, who tend to close their eyes to the other party's activities (accepted as a field of competence), feeling that they would have acted in a similar way. These tacit agreements contribute greatly to the consolidation of institutions. ${ }^{20}$ As a result, only a miniscule fraction of scandalous acts result in scandals. Moving the focus from transgressions to the protagonists' perceptions and mobilizations makes it easier to consider another central property of scandals, that is their configuration as a series of emergent properties, that is, feedback loops in which 'causes' produce 'effects' which in turn affect the 'causes'. This process is extremely important in determining changes in how the protagonists perceive the situation. ${ }^{21}$

A scandal depends on an entanglement of independent and reversible points of view produced in the light of mobilizations. Without these mobilizations, there is no scandal; if the mobilizations stop, the scandal stops. These mobilizations, which create and re-create each scandal, are highly dependent on changes in the protagonists' evaluations of the situation. They are linked to oscillations in perceptions of what is (im)possible, ${ }^{22}$ that is, evaluations that arise out of the action via the senses, calculations and habitus ${ }^{23}$ of interconnected players. If an individual's opinion of what is (un)feasible convinces that person to relay an accusation, other parties could do so, too, because people base their actions on their perceptions of what others are doing or will do. People are persuaded or dissuaded to move in a certain direction by their assessments of what others are likely to do and of what is/is not doable. Because perceptions of what is possible are interconnected, they can change very quickly, with one perception reflecting on another. People's contributions and their dependence on the 'context' (i.e. the meaning they give to their environment) depend on this reflective interplay. People act by observing others and react to fluctuations in their expectations. This is why scandals can abruptly produce a collective alignment $^{24}$ and, by doing so, invert the balance of power. For example, the Festina affair, which rocked the 1998 Tour de France, came to light because the 'law of silence' that had long been obeyed by most of the protagonists (cyclists, doctors, sports managers, journalists, organizers, politicians, etc.) was suddenly broken when the Festina team doctor was arrested in possession of a stock of performanceenhancing drugs and then cooperated with investigators by giving details of how teams obtained banned substances. Our main thesis is that analysing these variations in what the different players are prepared to do will provide insights into how scandals of any sort erupt, grow and die out. Hence, accurately mapping the sometimesdisconcerting variations in the feasibility of denouncing transgressions is central to understanding scandal, especially for explaining the collapse of collusions - a crucial factor in removing a protagonist's legitimacy. For example, in 2007, the credibility of the organizers of the Tour de France was threatened by desertions and threats of desertion by the media (two German television networks suddenly stopped broadcasting the race), sponsors (two major German companies stated they would 
not renew their sponsorship), the IOC (leading to a rumour that cycling would be excluded from the Olympics) and the Danish cycling federation (which excluded yellow jersey holder Michael Rasmussen from the national team for the world championships), etc.

An often-neglected aspect is that scandals evolve as they progress. Whether to continue or halt one's efforts, accuse or remain silent, desert or stay loyal, deny, counter-accuse or retract - all these decisions depend on their makers' evaluations of the situation. These inter-subjective evaluations may be approximate and fickle, but they are crucial to the relations between protagonists. Swept along by unforeseeable changes in relationships, new projections lead people to adopt a (new) position on whether to support or oppose a public accusation. A scandal's dynamic depends on these micro-turning points. ${ }^{25}$ This type of self-generation means that each scandal, rather than following a pre-established path, can be viewed as an open process whose players, location, duration, stakes, balances of power and outcomes are not fixed in advance. Instead, they depend on a complex series of thrusts and parries with uncertain and partly contingent outcomes. The size of a scandal depends on the size of the mobilization and the amplitude of the oscillations in perceptions of what is (im)possible. These two processes are correlated as the more the occupiers of a field are confronted with intrusions by outsiders, the more likely it is that these intrusions will affect their assessments and actions. Thus, in the case of the scandals affecting the Tour de France, the sudden and unexpected scrutiny of their actions by journalists, police officers, customs officers, investigating magistrates and sports ministers, etc. may have increased the temptation felt by some competitors to spill the beans about doping. Using a relational perspective to move on from studying the object of scandals to studying scandals as an object allows this type of dynamic to be resituated in the continuum of social relations. A scandal is a reconfiguring process involving the recombining of these relations between and within several sectors. The motors of this dynamic - multisectoral mobilizations and oscillations in perceptions of what is (im)possible - co-vary by varying the feasibility of denunciation.

Scandals can severely threaten the targeted institution, potentially wreaking havoc on its hierarchy, rules and agenda. This is why officials have to review their positions and, whether they like it or not, set in motion institutional countermeasures (implement reforms, suspend targeted staff, adopt or strengthen a code of ethics, etc.) in order to contain or take control of the accusation, as the desectorization generated by a scandal could be extremely dangerous for the institution's future. From the officials' point of view, the effectiveness of these countermeasures, which are sometimes very costly as they go against powerful interests (in 2012, the Union Cycliste Internationale stopped protecting Lance Armstrong after years of collusion), is measured in terms of their ability to stop the multisectoral mobilizations. Reducing these mobilizations and oscillations in perceptions of what is (im)possible allow the institution under threat to overcome the crisisby enablingit to regain some of its autonomy. If this is not achieved, the crisis worsens and becomes systemic (see Figure 1).

Our case study examines an on-going scandal and therefore faces a number of methodological problems, including the protagonists' lack of time and/or reticence to give interviews, no access to archive records, a fluid chronology and dependence on journalistic sources. However, this situation has the advantage of not being susceptible to the 'retrospective illusion'. ${ }^{26}$ 


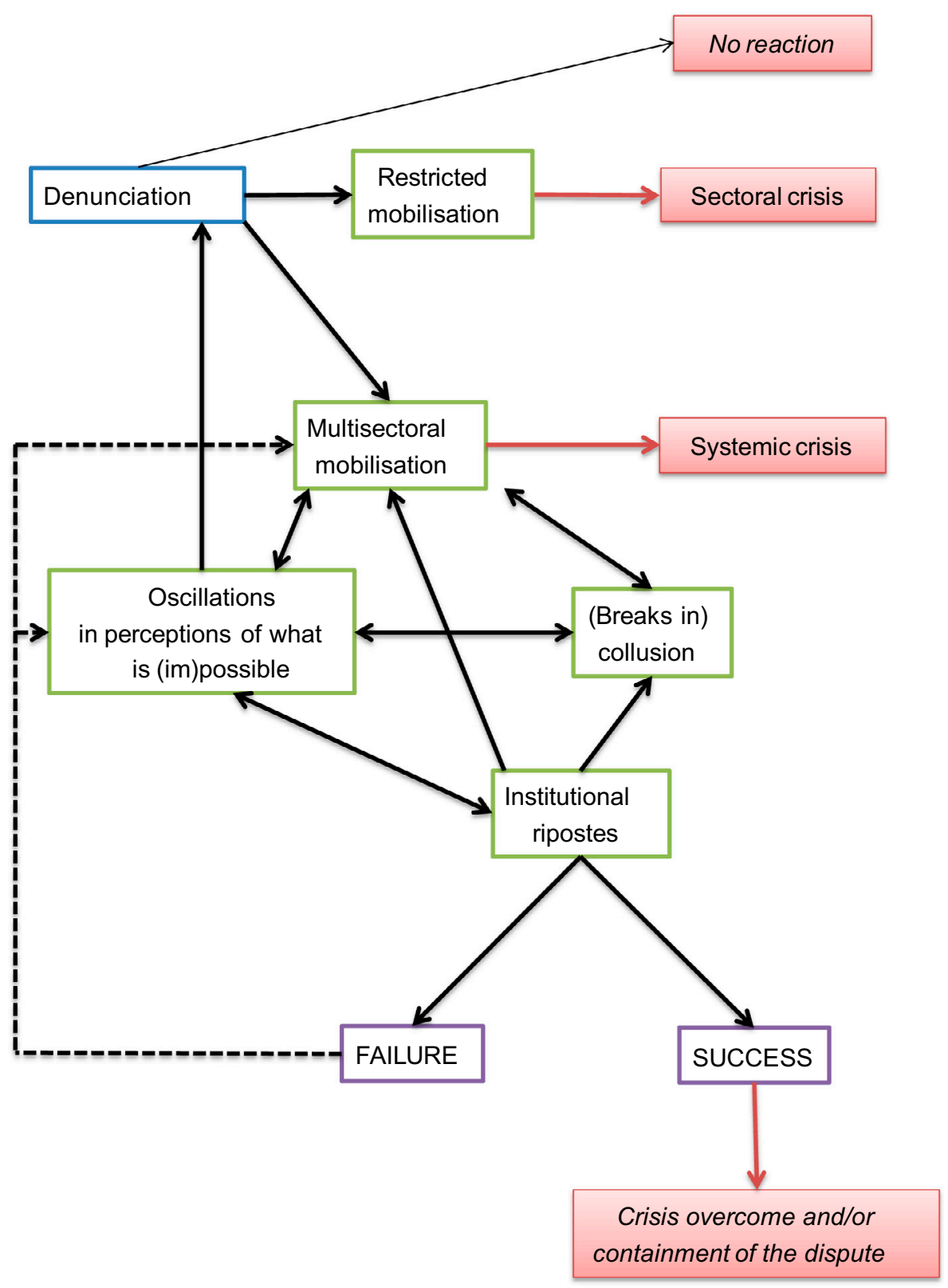

Figure 1. Model for analysing scandals.

Our sources for this research were newspaper articles from around the world (Switzerland, France, United States, Germany, Italy, United Kingdom - approx. 500 articles), FIFA files, general investigative media (Mediapart in France, Il Fatto Quotidiano in Italy, Der Spiegel in Germany, Sunday Times and The Guardian in the UK, New York Times in the USA, Le Temps in Switzerland), specialist sports newspapers (e.g. L'Equipe and France Football), materials produced by some of the 
protagonists (investigative journalists: Jennings, Yallop, a FIFA consultant, Pieth $^{27}$ ), documentaries (ARD, BBC, RTS, etc.), an indictment (USA v. J. Webb et al. ${ }^{28}$ ), NGO reports (Transparency International; Play the Game), governmental and intergovernmental reports $\left(\mathrm{FATF}^{29} ; \mathrm{GRECO}^{30}\right)$, the $\mathrm{IOC}^{31}$, and reports of measures made public by FIFA (FIFA.com), especially between 2010 and 2015. These data allowed us to reconstruct how the scandal's exceptional dynamic annihilated the customary ability of FIFA's leaders to protect themselves. We were also able to look back on earlier FIFA crises and therefore more clearly describe the context surrounding the FIFAgate.

\section{FIFA's resilience: neutralizing allegations}

Although allegations of corruption have been levelled at FIFA officials on numerous occasions throughout the federation's history, especially since João Havelange's long presidency (1974-1998), until 2015 FIFA had always been able to isolate its accusers and quash any litigation. Before analysing the measures introduced by FIFA to contain these conflicts, we will look back at the accusations and the people who made them, most of who were journalists or senior managers/staff at FIFA.

In his book How They Stole the Game, the English journalist and best-selling author David Yallop suggests that Blatter, then FIFA's secretary general, was elected president of FIFA (by 111 votes to 80 ) not just because of the support he was given by the powerful outgoing president, João Havelange, but also thanks to votes bought from African representatives. ${ }^{32}$ These allegations were never proven and Blatter won a legal battle to prevent the book being published in Switzerland. In 2006, the Scottish journalist Andrew Jennings, working for the BBC's Panorama programme, investigated allegations of bribes paid in relation to the attribution of the World Cup. This was the first of a long series of documentaries and books about corruption within FIFA, ${ }^{33}$ with Jennings willingly taking on the role of public accuser, as he had done previously in relation to corruption at the IOC and the attribution of the Olympic Games (1992, 2000). In 2010, journalists from The Sunday Times, a newspaper that had been in the front line of accusations of doping in cycling, published compromising recordings obtained by presenting themselves to FIFA officials as lobbyists for the USA's bid to host the World Cup. In April 2010, South African journalists associated with Jennings published a book ${ }^{34}$ lambasting FIFA for its predatory way of operating, accumulating revenues and tax breaks while leaving all expenditure to the host country. In January 2013, France Football began its 'Qatargate dossier', while, in June 2014, The Sunday Times claimed that FIFA's Qatari Vice-president, Mohamed Bin Hammam, had spent \$5 million to obtain votes, most notably from the presidents of 30 African federations, for Qatar's bid to host the World Cup. One of FIFA's most influential representatives, Jack Warner, was once again implicated. It was claimed that Warner, a Trinidadian businessman, FIFA vice-president and president of the Confederation of North, Central American and Caribbean Association Football (CONCACAF) since 1990, had accepted \$1.6 million from Bin Hammam. In April 2015, two Sunday Times journalists published The Ugly Game, ${ }^{35}$ a blistering account of how Qatar allegedly bought the votes of FIFA's executive committee members.

Criticisms by FIFA officials and mangers are by no means rare, especially in the run up to or following election congresses and executive committee votes to choose host countries for the World Cup. These stunts are picked up by the media and 
prolong infighting, but they are of no real consequence. In 2000, Germany was narrowly awarded the 2006 World Cup (by 12 votes to 11) ahead of South Africa, possibly thanks to the abstention of the Oceania Football Confederation's president, the New-Zealander Charles Dempsey. One of the reasons Dempsey gave for his subsequent resignation from the executive committee was the pressure he had been put under. In 2002, it was the turn of FIFA secretary general, Michel Zen-Ruffinen, to resign after noting in his report 'abuses of power' and Blatter's 'dictatorial' management. In May 2011, Blatter's challenger, Bin Hammam was accused by Chuck Blazer, the secretary general of CONCACAF, of attempting to buy votes at a meeting of Caribbean representatives by distributing envelopes containing $\$ 40,000$. He allegedly did this with the complicity of Jack Warner, who was suspended from FIFA during an internal enquiry and who then accused Blatter of making a donation of $\$ 1$ million to his confederation. The accusation was quickly swept aside and Bin Hammam withdrew shortly before the election, making Blatter the only candidate.

Accusations can also come from whistleblowers who take part in or who witness illicit transactions. In a documentary shown on the German public television channel ARD on 4 May 2015, a former employee of the Qatar bid repeated her accusations (published in France Football in December 2014), this time naming three African members of FIFA's executive committee who had been offered $\$ 1.5$ million 'encouragements' by the Qatar delegation. Nevertheless, no sanctions were handed down. More commonly, FIFA is called to task, or even targeted, by critical reports from a number of institutions (FATF, 2009; Transparency International, 2011). Because these accusations are not just allegations by journalists and/or insiders and are in the public domain, FIFA is forced to react.

Through a repertoire of actions ranging from threatening libel suits or sacking one or more administrators to adopting a code of ethics or reforming the federation's rules, FIFA is usually successful in quashing such accusations. Thanks to its crisismanagement experts, the co-option of members of internal commissions of inquiry and (self-)censorship, investigations intended to get to the bottom of allegations always remain confidential and only the resulting decisions are divulged. This is also the case for external checks, such as those carried out by the auditors KPMG, which revealed hardly any irregularities in FIFA's accounts for 2007-2010. Critical voices within FIFA are removed by pushing people to resign (Michel Zen-Ruffinen in 2002, the marketing director Guido Tognoni in 2003), expelling representatives who lack protection, often those from small federations, launching disciplinary procedures, which have been unending since 2013 to the detriment of officials from SriLanka, Mongolia, Nepal, India and Tahiti, and, more rarely, sanctioning important officials (vote carriers).

The reforms introduced by FIFA are one of the main ways in which it responds to mobilizations it sees as hostile. An ethics committee and code of ethics were set up in 2004, with revisions added to the code of ethics in 2006, 2009 and 2012. In 2011, following Blatter's campaign promise to steer the 'FIFA boat back into clear, transparent waters', an independent governance committee was formed, presided by Mark Pieth, a Swiss university professor and expert in governance. Some of the recommendations contained in Pieth's report, ${ }^{36}$ including dividing the ethics commission into investigatory and adjudicatory chambers, were adopted. The amendments to FIFA's statutes were put to the vote at the federation's congress on 25 May 2012 and massively approved. They included strengthening the audit and compliance 
commission, introducing a code of conduct, appointing a woman to the executive committee, appointing two women as observers, and attributing one World Cup at a time. Age limits and length of mandate were not addressed, but the measures that were passed appeared to increase FIFA's legitimacy. Nevertheless, they did nothing to challenge the organization's clientelistic culture, made up of clanism, conflicts of interest and nepotism (one of Blatter's nephews heads Infront, the company responsible for managing FIFA's TV rights). Pieth called this system a 'patronage network'. These shady dealings are enough to satisfy the 24 members of the executive committee and 10 directors, who received a total of $\$ 36.3$ million in 'indemnities' in 2014, ${ }^{37}$ and FIFA's partners, especially as the federation's turnover has never grown so quickly. Between 2011 and 2014, FIFA's revenues amounted to $\$ 5.7$ billion, most of which came from World Cup television rights (\$2.45 billion in 2014, 20 times more than in 1998) and sponsorship contracts (\$1.6billion). During the same period, FIFA redistributed over $\$ 1$ billion to national federations. These funds are intended to finance development projects, but they also end up in the pockets of individuals who, in return, provide 'packets of votes' for the president. These powerful forms of collusion are based on an institutional architecture that sanctions the 'political' power of the continental associations and the independence of national associations, over which the Zurich head office has no direct control and whose officials are careful to keep their eyes shut.

The way in which the collapse of International Sport and Leisure (ISL) was handled shows that FIFA's ability to protect itself also depends on the benevolence of other institutions. ISL was founded in 1982 by the head of Adidas, Horst Dassler, as a specialist sports marketing company and had exclusive responsibility for managing FIFA's media rights during the 1990s. Nevertheless, the company went bankrupt in 2001. An investigation was carried out by Swiss magistrates, but the case file was not made public until 2012. In fact, ISL had paid out CHF160 million in bribes between 1989 and 2001. ${ }^{38}$ According to documents quoted by Play the Game, former FIFA president J. Havelange and his son-in-law, Ricardo Teixeira, the president of the Brazilian Football Confederation (CBF) and a member of FIFA's executive committee, received CHF41 million but Swiss magistrates refused to prosecute. In 2011, Havelange resigned from the post he had held at the IOC for 48 years and in July 2013 he stepped down as honorary president of FIFA. In 2012, Teixeira also left FIFA, for 'medical reasons', after 22 years at the head of the CBF, where he had survived numerous allegations of embezzlement without ever being convicted. At FIFA, the new ethics commission cleared Blatter in 2013: 'President Blatter's conduct could not be classified in any way as misconduct with regard to any ethics rules ....... (even if it) may have been clumsy'.

The collusions that helped protect FIFA from the accusations made against it arise from a vast network of inter-institutional relations, starting with those that prevail in Switzerland. Corrupt practices in the private sector are not prosecuted automatically and it was not until 2004, in response to pressure from the OECD (and its Financial Action Task Force - FATF) and the GRECO, that the Swiss government made private corruption a misdemeanour (included in the Unfair Competition Act but not in the Penal Code). Until then, bribes paid abroad by Swiss companies had been tax deductible! On the grounds that international sport organizations are not subject to competition, on 10 November 2004, Switzerland's Federal Council (government) assured them they would not be subject to the Unfair Competition Act. Corrupt practices would be prosecuted only if one or more of the protagonists 
(corrupter or corrupted) filed a complaint. As a result, there were no convictions for private corruption between 2004 and 2014. This form of immunity, alongside other powerful collusions (banking secret, failure to prosecute tax fraud, tolerance of tax evasion, little regulation, low corporation tax $-4.25 \%$ ) and other advantages (political stability, protection of privacy) explain why around 60 international sports organizations are based in Switzerland, earning the country more than CHF1 billion every year. Nevertheless, between 2000 and 2014, 25 of the 35 parliamentary speeches concerning FIFA mentioned suspicions of corruption. ${ }^{39}$ Although the legal pressure in Switzerland has increased a notch, a large majority of MPs are happy to let the status quo continue.

On 26 September 2014, Hans-Joachim Eckert, the president of the adjudicatory chamber of the ethics commission, minimized the conclusions of a report by the president of the investigatory chamber, Michael J. Garcia, into suspicions of corruption in the attribution of the 2018 and 2022 World Cups. FIFA announced that it would not publish the report, as the requirement to maintain confidentiality contained in its code of ethics did not allow it to do so. Nevertheless, on 18 November 2014, Eckert ordered FIFA to provide Switzerland's attorney general with a copy of Garcia's report. This ruling was not enough to stop the former U.S. Attorney for the Southern District of New York resigning (on 17 December) because of his indignation over the censorship of his report. Although for decades many players inside and outside FIFA saw the federation as almost untouchable, FIFA's resilience was situational - as long as accusations were not simultaneously and massively relayed in several fields, the organization could easily maintain an image of stability.

\section{FIFAgate: how the scandal damaged the organization's legitimacy}

For many years, the accusations of corruption against FIFA led to no more than internal sanctions and sectoral crises. So, why did things change in 2015? In order to grasp the size of the scandal and the institution's sudden vulnerability it is necessary to consider the multisectoral and simultaneous dimension of the accusations that, from 27 May, turned the situation upside down and allowed the unthinkable to happen.

On 27 May, the eve of the 65th FIFA congress, the United States Department of Justice (DoJ) published a 161-page indictment drawn up by Brooklyn federal court on 20 May and charging 14 defendants (9 FIFA officials, including 2 vice-presidents, and 5 sports company executives). The indictment refers to corruption that had become 'endemic' (United States v. J. Webb, 32) 'over a period of approximately 25 years' within the FIFA 'system', and lists 47 counts of racketeering, fraud, money laundering, bribes and kickbacks amounting to $\$ 150$ million, etc. The investigation had taken several years and was based on the Racketeer Influenced and Corrupt Organizations Act (RICO). The bribes related to FIFA's presidential election in 2011, broadcasting rights, marketing contracts for competitions such as the Copa America and sponsorship agreements. Ten other defendants pleaded guilty between July 2013 and May 2015, including Blazer and two of Warner's sons. Over a period of 19 years, Blazer ('Mr 10\%') had accumulated \$11 million that he had not declared to the Internal Revenue Service (IRS). As a result, he resigned as secretary general of CONCACAF and pleaded guilty to 10 charges (racketeering, money laundering, tax evasion, etc.) in an American court, with which he had secretly cooperated for 16 months while remaining a member of FIFA's executive committee. 
The collusion between Warner and Blazer collapsed in 2010 when Warner supported Qatar's bid for the World Cup and Bin Haman's bid to become FIFA president, while Blazer had supported the United States and Blatter.

In conjunction with the publication (on the Internet) of this indictment, the Swiss police, acting on an American warrant, arrested seven officials in a luxury hotel in Zurich (New York Times journalists, tipped off by Brooklyn's district attorney, were at the scene). FIFA's head office was searched under a warrant issued by Switzerland's attorney general, who was investigating the attribution of the 2018 and 2022 World Cups, while the US authorities searched CONCACAF's headquarters in Miami. At the same time, the head of the DoJ, Loretta Lynch (who, importantly, had supervised the investigation as a federal prosecutor in Brooklyn) held a news conference in New York alongside the heads of the FBI, James Comey, and of the IRS's Criminal Investigation Division, Richard Weber, who spoke of a 'World Cupof fraud' spanning 'at least two generations of soccer officials'. Lynch stated: 'the indictment alleges corruption that is rampant, systemic, and deep-rooted both abroad and here in the United States'. ${ }^{40}$ The cooperation between the Swiss and American authorities surprised many commentators ('Switzerland is playing an unexpected double role ${ }^{41}$ ), as there was no solid legal basis for it. In fact, this action was part of the wider cooperation between the USA and Switzerland that had arisen out of the banking scandals involving Swiss UBS (fined $\$ 780$ million) and Crédit Swiss (fined \$2.6 billion, paid in 2014 in order to keep its trading licence in the USA), which were prosecuted under the 2010 Foreign Account Tax Compliance Act (FATCA), which came into force in 2014.

This operation, which was unprecedented in terms of the resources employed and its multi-level coordination, led to an almost immediate response from FIFA. On 27 May, the ethics commission's adjudicatory chamber temporarily suspended 11 FIFA representatives. Another three officials were suspended between 28 May and 2 June. FIFA's director of communications, Walter de Gregorio, repeatedly stated that Blatter was not implicated and many people, including Blatter's declared opponents, believed he would be re-elected president once the scandal had blown over. At the end of a congress marked by an unprecedented media mobilization and demonstrators brandishing signs reading 'Game over for Blatter', the president's reelection (by 133 votes against 73 votes for Prince Ali, who decided not to force a second round) suggested that the 'unbudgeable' would extricate himself again: 'Despite the scandals, Sepp Blatter manages to win', 42 'The secrets of the unsinkable "captain". 43 Nevertheless, the chairman of the English Football Association said he would be 'very surprised' if Blatter were to last more than two years.

However, the scale of desertions exceeded all expectations, precipitating Blatter's fall. In fact, most Swiss newspapers had already turned against him by 28 May: 'Mr .Blatter, go' was the title of the editorial of the Vaud canton's biggest daily paper, 24 Heures; 'Blatter has lost his credibility' was the headline in Le Matin, while an editorial in Le Temps announced 'The end of impunity' and L'Hebdo wrote of 'Sepp Blatter's seven deadly sins'. In the UK, members of parliament called for a boycott of the 2022 World Cup and, as a gesture of protest, England's FIFA representative David Gill refused to serve on the executive committee. At the same time, FIFA's corporate sponsors (more than a third of its revenues) voiced their fears by threatening to review their sponsorship, as the scandal had given them the opportunity to renegotiate their contracts. Long-term critics of the 'FIFA system' were even harsher, with Guido Tognoni writing: 'for the last 40 years, since Havelange was 
enthroned, FIFA has had a culture of corruption. Blatter didn't start it, but he has always tolerated corruption. It was a way of staying in power' (he estimated Blatter's annual 'salary' to be CHF15 million). ${ }^{44}$ Two members of the Swiss parliament put forward an action plan to combat corruption in sport and in its 3 June edition The New York Times noted 'the widespread impression of FIFA as a corrupt rogue state'. At the same time, the European newspapers behind many of the investigations of FIFA renewed their enquiries (The Guardian and The Sunday Times in England, Mediapart in France, Il Fatto Quotidiano in Italy, Der Spiegel in Germany, etc.). Some referred to 'practices worthy of a mafia clan', ${ }^{45}$, and it became quite common to draw parallels between FIFA and a mafia organization. Others, which had supported Blatter, distanced themselves from him.

Nevertheless, some collusions continued. By sitting next to Blatter at the opening of the congress and having defended him the day before at the Swiss Media Forum, Switzerland's Minister of Defence and Sports Ueli Maurer, showed his continuing support, while Peter Gilliéron, the president of the Swiss Football Association and a member of UEFA's executive committee, carefully watched his words. In the eyes of some of FIFA's staff, Blatter had not lost his credibility and on 3 June he was applauded at FIFA headquarters. The same day, Switzerland's Council of States (the upper chamber of parliament) refused, by 23 votes to 22 , to follow the Federal Council's recommendation on prosecuting private corruption, which would not, therefore, be prosecuted automatically. It seemed it was still possible to publicly acknowledge instances of give and take. For example, the president of the French Football Federation, who had supported Blatter's election because France had just been awarded the 2019 Women's World Cup, claimed: 'our relations with FIFA are extremely good (...) I like to return a favour when someone has given us something, 46

Four days after his re-election, Blatter, in a dramatic turn, announced: 'I have decided to lay down my mandate at an extraordinary elective congress'. This decision was taken following the accusations levelled at FIFA's secretary general and Blatter's right-hand man, Jérôme Valke, in an article in The New York Times about a payment of $\$ 10$ million to CONCACAF in 2008 as a 'commission' in exchange for votes to award the 2010 World Cup to South Africa. This turnaround made denouncing FIFA much easier: 'Blatter, the fall of FIFA's big boss', ran the headline in Le Nouvelliste on 3 June, a daily where Blatter worked in the $1960 \mathrm{~s}$, ${ }^{47}$ with the American media suggesting that the FBI was investigating Blatter. The destruction of Blatter's and FIFA's reputations led Swiss political leaders to voice their fears about Switzerland's image. ${ }^{48}$ The heads of several Western governments (especially in the UK, France and Germany) simultaneously came out against Blatter, something that only the British prime minister, in 2010, and the Brazilian president, Dilma Roussef, had done previously. On the other hand, President Putin gave Blatter his official support against 'yet another flagrant attempt (by the United States) to extend its jurisdiction to other states' ${ }^{49}$ These official positions reflected other powerful geopolitical interests, with governments considering sport an important vector of soft power. ${ }^{50}$

Many people quickly saw how vulnerable FIFA had become, a turnaround (effect) resulting from a series of defections (cause), which, in turn, facilitated these defections, hence the effect acted on the cause in a form of expanding loop. It is in this way, as an emergent process, that a scandal can so rapidly disrupt a powerful institution. The crisis achieved a dimension never before seen at FIFA, which had to 
face a concomitance of large oscillations in perceptions of what was (im)possible. 'It is a shock, the surprise we no longer expected to happen, we had got so used to seeing Sepp Blatter weather every storm'; 'The extent of the abuses exposed in recent days is such that other continents, other federations could be affected' ${ }^{51}$ The term FIFAgate, first used as a Twitter hashtag on 27 May and quickly picked up by most other media, ${ }^{52}$, neatly summarizes this transformative event. The scandal has affected positions and stances, with the head of the audit and compliance commission, Domenico Scala, who was given the task of devising a programme of reform, suddenly being seen as a 'Mr.Clean' and the reformer of FIFA. The extent of the turnaround in the thinkable that produced and was produced by the scandal forced many people to change their plans. These interdependent moves also explain why, on 29 May, after years of unsuccessful attempts, Brazilian senators hastily decided to set up a parliamentary commission of enquiry into the $\mathrm{CBF}$, and why the Brasilia prosecutor, who used to consider Teixeira 'a too big fish for me', changed her mind and decided to prosecute him for money laundering and fraud. Brazilian police had found that several of his bank accounts had been swollen by 'unusual' payments totalling $€ 133.5$ million between 2009 and 2012, when Teixeira was president of the 2014 World Cup organizing committee. Several attacks that had formerly been considered too risky, such as threatening to withdraw the 2018 and 2022 World Cups, were suddenly seen as doable, especially in the eyes of British and American officials. For example, the chairman of the English Football Association said: 'We can go back and look at those two World Cups. If I was in Qatar today, I wouldn't be feeling too confident'. 53

Encouraged by the multisectoral mobilizations and large oscillations in perceptions of the (im)possible, FIFAgate has triggered a flood of other revelations and accusations. On 4 May, John Delaney, the president of the Irish Football Federation, admitted that his federation had accepted a large sum of money from FIFA in exchange for not pressing a complaint against France for a refereeing error during a qualifying match for the 2010 World Cup (a figure of $€ 5$ million has been suggested). On 25 October, the German World Cup affair resurfaced. Der Spiegel claimed that a slush fund had been set up and, for the first time, Franz Beckenbauer admitted 'a mistake' had been made. Some allegations were made in order to colour opinions of certain protagonists. For example, on 3 June, the DoJ made Blazer's confession public. The same day, in an interview with the Frankfurter Allgemeine Zeitung, Lynch said information had been passed on to other countries, including Switzerland.

In this context of great uncertainty linked to the desectorization of the dispute, the standings of the leading contenders to succeed Blatter as FIFA president fluctuated as the scandal went on. Originally the firm favourite due to his new opposition to Blatter, Michel Platini soon found himself the subject of new allegations. Prince Ali went on the attack and Blatter was quick to point out that Platini had voted for Qatar (recruitment of his son, agreement between president Sarkozy, Qatar's crown prince Al-Thani, his prime minister and a representative of Colony Capital, the owners of PSG, during a dinner Platini attended at the Elysée Palace on 23 November $2010^{54}$ ). On 25 September, Switzerland's attorney general began investigating Blatter for 'disloyal management' and 'abuse of trust' in relation to the signature of 'an unfavourable contract' with the Caribbean Football Union. Blatter was also accused of making a 'disloyal payment' of $€ 1.83$ million to Platini, with the result that Platini lost a section of his support from the French media. On 2 October, 
FIFA's largest American sponsors (Coca-Cola, McDonald's, Visa, Budweiser) demanded Blatter's immediate resignation after a criminal investigation against him was launched in Switzerland. On 8 October, Platini, Blatter and Valcke were given 90-day suspensions by the ethics committee. In addition, a former FIFA Vicepresident, Chung Mong-oon (candidate in the forthcoming presidential election), was suspended for six years and fined CHF100,000. At the deadline for registering as a candidate in the presidential election, on 26 October, Platini was one of eight candidates, but the decision by UEFA's executive committee to support the candidacy of its secretary general, Gianni Infantino, was seen as a 'disavowal of Platini'. On 21 December, FIFA's ethics committee finally sanctioned Platini and Blatter for 'conflict of interests' and 'disloyal management', suspending them for eight years and imposing heavy fines.

At FIFA's extraordinary congress on 26 February 2016, Gianni Infantino was elected the organization's new president and a number of reforms of governance were passed. These included ensuring a clear separation of political and managerial powers, reducing the number of committees from 26 to 9, limiting the president's term of office (12 years), requiring individuals to disclose their remuneration, improving recognition for women and increasing their role and imposing a requirement to respect human rights. Some reforms, such as the requirement to provide independent annual audits and create independent judicial bodies to ensure the separation of powers at all levels of football, also apply to member associations and confederations. Most of these measures were proposed by a reform committee that had been formed in August 2015 along similar lines to the reform committee set up by the IOC 15 years ago. In fact, for its protagonists, FIFAgate is reminiscent of the scandal surrounding the awarding of the Olympic Games to Salt Lake City in 1998, especially as the subsequent measures taken by the IOC were generally seen 'as effective, if partial'. ${ }^{55}$ Hence, the way IOC managed the Salt Lake City scandal ('responsible autonomy ${ }^{, 56}$ ) served as a 'focal point" ${ }^{57}$ for expectations and a possible solution. ${ }^{58}$ Hence, it was widely felt that the solutions introduced by the IOC could provide a model for overcoming the FIFAgate crisis. FIFA's riposte of 11 August, when the federation announced the creation of the 2016 reform committee, to be presided by 77-year-old Swiss lawyer, François Carrard, a former general manager of the IOC and the coordinator of the 'IOC 2000' reform committee, can certainly by interpreted in this way.

Unlike the reforms previously implemented by FIFA, these measures are being supervised by external institutions (DoJ, FBI). In fact, the US Department of Justice required FIFA to go victim within the framework of corruption cases. The DoJ's work at FIFA's headquarters is being carried out in conjunction with an American law firm (Quinn Emanuel), which, since June 2015, has allocated considerable resources to the investigation of corruption cases, 'a victim of which FIFA would have been'. As a result, the unthinkable happened - for the first time, FIFA accused a country (South Africa) of buying the right to host the World Cup, moreover, a judicial dissolution of the FIFA is no longer excluded. Due to the pressure of the mobilizations that paralyzed the executive committee (11 out of 24 members are being prosecuted), the institution's heteronomy goes with the empowerment of some of its components (the audit and compliance committee, reform committee). In an interview published on 7 June 2015, the president of FIFA's audit and compliance committee, D. Scala, stated that Russia and Qatar would possibly no longer be eligible to host the FIFA World Cup competitions in 2018 and 2022 if proof of bribery 
was found. Nevertheless, FIFA's new strongman felt he had to resign following Gianni Infantino's decision at the FIFA Congress in Mexico City in May 2016, which passed an amendment giving FIFA's executives the power to appoint and sack the presidents of the ethics and audit commissions. Hence, the FIFA crisis appears to be continuing, as its new executives, in contrast to the IOC in 2000, have been unable to contain the never-ending series of disputes (revelations at the beginning of June: $\$ 80$ million of suspicious payments to Blatter and two other top officials, controversy over the new president's salary and the appointment of the new secretary general, accusations by Blatter of rigging of the draws for major competitions, etc.).

\section{Conclusion}

We have shown how, for many years, FIFA's executives managed to contain the mobilizations that formed around allegations of corruption. However, when these mobilizations became multisectoral, on 27 May 2015, they created an uncontrollable and self-perpetuating serial-feedback process that, most importantly, made it easier for new denunciations to emerge. Hence, within just a few weeks, numerous protagonists with a variety of motives came forward to level accusations at FIFA's top executives, leading (at last) to a vehement public outcry against the corrupt practices within the federation.

The primary objective of this article is to propose a new theoretical framework for analysing scandals. A scandal is both the product and the producer of changing anticipations, a complex, moving and disruptive reconfiguration of the relationships inside and between several fields. As for any huge scandal, FIFAgate can be understood in terms of a sequential phase of multisectoral mobilizations (across the legal, political, economic, media and sport fields) linked to major changes in the actors' perceptions, which allow them to do things they would previously considered unthinkable. These new perceptions are conducive to new kinds of action. They are self-fulfilling, but still very contingent and reversible. The feasibility of denunciation can vary enormously during this process, which is why scandals are unanticipated and uncontrollable. They also tend to occur in clusters, as can be seen in the web of scandals that emerged in the wake of FIFAgate (IAAF in November 2015; match fixing in tennis January 2016; doping by British athletes in April 2016).

The ultimate lesson to be learnt from FIFAgate is that the involvement of one or more powerful institutions (in this case, the US DoJ and FBI) is a necessary but insufficient condition for a scandal to occur, as mobilizations must be multisectoral and simultaneous if they are to generate a crisis within the collusions that underlie the formation of a culture of corruption within an institution.

\section{Disclosure statement}

No potential conflict of interest was reported by the authors.

\section{Notes}

1. Radio Suisse Romande, Forum, August 28, 2014.

2. Bourdieu, Outline of a Theory of Practise.

3. Rayner, De quoi les scandals sont-ils faits? (From what scandals are made?). 
4. Dard et al., Scandales et corruption à l'époque contemporaine; Rose-Akerman, Corruption and Government, Causes, Consequences, and Reform.

5. Cartier-Bresson, Economie politique de la corruption et de la gouvernance; Johnston, The Search for Definitions.

6. Uslaner, Corruption, Inequality, and the Rule of Law.

7. Giannakopoulos, Maras, and Tänzler, 'Perceptions of Corruption and Their Relevance to Anti-corruption Measures'; Lascoumes, Une démocratie corruptible.

8. Duret and Trabal, Le sport et ses affaires. 'Une sociologie de la justice de l'épreuve sportive'; Hill, 'How Gambling Corruptors Fix Football Matches'.

9. Jennings, Foul! The Secret World of FIFA; Jennings, Omertà: Sepp Blatter's FIFA Organised Crime Family; Yallop, How They Stole the Game.

10. Transparency international, Safe Hands: Building Integrity and Transparency at FIFA; Transparency International, Transparency International Football Governance League Table.

11. Masters, 'Corruption in sport'.

12. Becker, 'World cup 2026. Now accepting bribes'.

13. Sudgen and Tomlinson, FIFA and the Contest for World Football; Mason, Thibault, and Misener, 'An agency theory perspective on corruption in sport'; Chappelet, 'Towards better olympic accountability'; Pielke, 'How can FIFA be held accountable?'; Tomlinson, The Men, the Myths and the Money; Geeraert and Drieskens, 'The EU controls FIFA and UEFA'.

14. Bayle, 'Olympic social responsibility'; Chappelet, 'Corporate Social Responsibility'; Parent and Chappelet, 'Olympics, Social Responsibility and Stakeholders'.

15. Palmer, Assessing the sociology of sports: on controversies and scandals.

16. Rayner, 'Corruption in France: Structural and Contextual Conditions'.

17. Sherman, 'The mobilisation of scandal'.

18. Adut, On Scandal, Moral Disturbances in Society, Politics and Art ; Thompson, Political scandal, Power and Visibility in the Media Age.

19. Dobry, Sociologie des crises politiques.

20. Ibid.

21. Rayner, 'De quoi les scandals sont-ils faits?' (From what scandals are made?).

22. Rayner, 'Les scandals politiques, l'opération 'Mains propres' en Italie'.

23. Bourdieu, Outline of a Theory of Practise.

24. Ermakoff, Ruling Oneself Out.

25. Rayner, Dynamique du scandale.

26. Dobry, Sociologie des crises politiques.

27. Pieth, Reforming FIFA.

28. United States v. J Webb et al., District Court, Eastern District of New York, 2015.

29. FATF, Money laundering through the football sector.

30. GRECO, 15th General Activity Report (2014).

31. IOC, Annual Report 2014 - Credibility, Sustainability and Youth.

32. Yallop, How They Stole the Game.

33. Jennings, Foul! The Secret World of FIFA; Jennings, Omertà: Sepp Blatter's FIFA Organised Crime Family.

34. Schulz Herzenberg, Player and Referee.

35. Blake and Calvert, The Ugly Game.

36. Pieth, Reforming FIFA.

37. Jennings, The Dirty Game.

38. Ibid

39. Le Temps, May 30, 2015.

40. Financial Times, May 28, 2015.

41. 24 Heures, May 28, 2015.

42. Le Temps, May 30, 2015.

43. 24 Heures, May 30, 2015.

44. L'Hebdo, May 28, 2015.

45. L'Hebdo, June 4, 2015.

46. Reuters, May 28, 2015.

47. Bernaudeau, Blatter, un monde à vendre. 
48. 'Switzerland fears for its image', Le Matin, June 4, 2015.

49. The New York Times, May 29, 2015.

50. Gygax, Olympisme et Guerre froide culturelle, le prix de la victoire américaine.

51. Le Temps, June 3, 2015.

52. 'What is now commonly referred to as FIFAgate', Le Monde, June 6, 2015.

53. Wall Street Journal, June 2, 2015.

54. Auclair and Champel, FIFAgate.

55. Chappelet, 'Towards better olympic accountability'.

56. Chappelet, 'Autonomy and governance'.

57. Schelling, The Strategy of Conflict.

58. 'The IOC, an example to follow?', 24 Heures, June 5, 2015.

\section{References}

Adut, A. On Scandal, Moral Disturbances in Society. Politics and Art. Cambridge: Cambridge University Press, 2008.

Auclair, P., and E. Champel FIFAgate. Paris: Michel Lafon, 2015.

Bayle, E. 'Olympic Social Responsibility: A Challenge for the Future'. Sport in Society 19, no. 6 (2016): 752-766. doi:10.1080/17430437.2015.1108646.

Becker, R. "World Cup 2026 Now Accepting Bribes: A Fundamental Transformation of FIFA's World Cup Bid Process." The International Sports Law Journal 13, no. 1-2 (2013): 132-47.

Bernaudeau, E. Blatter, Un Monde à Vendre [A World to Sell]. Paris: J-M. Lafont, 2015.

Blake, H., and J. Calvert. The Ugly Game. The Qatari Plot to Buy the World Cup. New York: Simon \& Schuster, 2015.

Bourdieu, P. Outline of a Theory of Practice. Cambridge: Cambridge University Press, 1977.

Cartier-Bresson, J. Economie Politique De La Corruption Et De La Gouvernance [Political Economy of Corruption and of Governance]. Paris: L'Harmattan, 2008.

Cartier-Bresson, J. Economie Politique De La Corruption Et De La Gouvernance [Political Economy of Corruption and of Governance]. Paris: L'Harmattan, 2008.

Chappelet, J.-L. 'Corporate Social Responsibility: A New Frontier for the International Olympic Committee'. In Social Responsibility and Sustainability in Sports, ed. P. Rodríguez, S. Késenne and H. Dietl, 17-29. Asturias: Universidad de Oviedo, 2009.

Chappelet, J.-L. 'Towards Better Olympic Accountability'. Sport in Society 14 (2011): 319-31.

Chappelet, J.-L. 'The Global Governance of Sport: An Overview'. In Routledge Handbook of Sport Policy, ed. I. Henry and L.-M. Ko, 63-74. New York: Routledge, 2013.

Chappelet, J.-L. 'Autonomy and Governance: Necessary Bedfellows in the Fight against Corruption in Sport'. In Global Corruption Report 2015: Sport, 45-60. Berlin: Transparency International, 2015.

Dard O., J. Engels, A. Fahrmeir, and F. Monier Scandales Et Corruption à L'époque Contemporaine [Scandals and corruption at the contemporary period]. Paris: Armand Collin, 2014.

Dobry, M. Sociologie Des Crises Politiques [Sociology of Political Crisis]. Paris: PFNSP, 1986.

Duret, P. and P. Trabal. Le Sport Et Ses Affaires. Une Sociologie De La Justice De L'épreuve Sportive [Sport and scandals. A sociology of the justice in sport]. Paris: Métailié, 2001.

Ermakoff, I. Ruling Oneself Out. A Theory of Collective Abdication. Durham: Duke University Press, 2008.

FATF. Money Laundering through the Football Sector. 2009. Available at: http://www.fatf-gafi. org

Geeraert, A., and E. Drieskens 'The EU Controls FIFA and UEFA: A Principal-Agent Perspective'. Journal of European Public Policy (2015): 1-19.

Giannakopoulos, A., K. Maras, and D. Tänzler 'Perceptions of Corruption and Their Relevance to Anti-Corruption Measures: Research Findings of the EU-Project 'Crime and Culture". In Korruption - Forschungsstand, Methodische Ansätze, Handlungsmöglichkeiten, ed. S. Thiel and T. Kliche, 115-51. Lengerich: Pabst Science Publishers, 2011. 
GRECO. 15th General Activity Report (2014). Strasbourg: Council of Europe, 2015. Available at: www.coe.int/greco

Gygax, J. Olympisme Et Guerre Froide Culturelle, Le Prix De La Victoire Américaine. Paris: L'Harmattan, 2012.

Hill, D. 'How Gambling Corruptors Fix Football Matches'. European Sport Management Quarterly 9 (2009): 411-32.

IOC. 2014. Annual Report 2014 - Credibility, Sustainability and Youth. Available at: http:// www.olympic.org/Documents/THE\%20IOC/Annual_Report/ 2014 IOC AnnualReport ENG onscreen.pdf

Jennings, A. The Great Olympic Swindle. New York: Simon \& Schuster, 2000.

Jennings, A. Foul! the Secret World of FIFA: Bribes, Vote Rigging and Ticket Scandals. London: HarperSport, 2006.

Jennings, A. 'Investigating Corruption in Corporate Sport: The IOC and FIFA'. International Review for the Sociology of Sport 46, no. 4 (2011): 387-98.

Jennings, A. Omertà: Sepp Blatter's FIFA Organised Crime Family. Transparency Books, 2014. Berlin.

Jennings, A. The Dirty Game: Uncovering the Scandal at FIFA. Century, 2015. London.

Jennings, A., and V. Simson The Lords of the Rings: Power, Money and Drugs in the Modern Olympics. New York: Simon \& Schuster, 1992.

Johnston, M. 'The Search for Definitions: The Vitality of Politics and the Issue of Corruption'. International Social Science Journal 149 (1996): 321-36.

Lascoumes, P. Une Démocratie Corruptible [A Corruptible Democraty]. Paris: Seuil, 2011.

Mason, D.S.L. 'An Agency Theory Perspective on Corruption in Sport: The Case of the International Olympic Committee'. Journal of Sport Management 20, no. 1 (2006): $52-73$.

Masters, A. 'Corruption in Sport: From Playing Field to the Field of Policy'. Policy and Society 34(2) (2015): 21-32.

Palmer, C. 'Assessing the Sociology of Sport: On Controversies and Scandals'. International Review for the Sociology of Sport 50 (2015): 558-62.

Parent, M. and J-L. Chappelet. 'Olympics, Social Responsibility and Stakeholders.' In Routledge Handbook of Sport and Corporate Social Responsibility, ed. J. L. Paramio Salcines, K. Babiak, and G. Walters, 2018-19. New York: Routledge, 2009.

Pielke, R. 'How Can FIFA Be Held Accountable?' Sport Management Review 16 (2013): 255-67.

Pieth, M. Reforming FIFA. St. Gallen: Dike Verlag, 2014.

Rayner, H. Les Scandals Politiques, L'opération "Mains Propres" En Italie [Political scandals. Operation "own hand" in Italia]. Paris: Michel Houdiard Editeur, 2005.

Rayner, H. Dynamique Du Scandale. Paris: Le Cavalier Bleu Editions, 2007.

Rayner, H. 'De Quoi Les Scandals Sont-Ils Faits?' [From what scandals are made?] Traverse 3 (2015): 33-45.

Rayner, H. 'Corruption in France: Structural and Contextual Conditions'. In The Social Construction of Corruption in Europe, ed. D. Tänzler, K. Maras and A. Giannakopoulos, 107-32. Aldershot: Ashgate, 2012.

Rose-Ackerman, S. Corruption and Government, Cambridge: Cambridge University Press, 1999.

Schelling, T. The Strategy of Conflict. Cambridge, MA: Harvard University Press, 1960.

Schenk, S. What Should FIFA Do about Corruption: Version 2.0? Space for Transparency, Transparency International. http://blog.transparency.org/2011/06/09/what-should-FIFA-doabout-corruption-version-2-0, 2011.

Schulz Herzenberg, C., ed. Player and Referee: Conflicting Interests and the 2010 FIFA World Cup. Pretoria: Institute for Security Studies, 2010.

Sherman, L.W. 'The Mobilisation of Scandal'. In Political Corruption, a Handbook, ed. A. Heidenheimer, M. Johnston and V.T. LeVine, 887-912. New Brunswick, NJ: Transaction Publishers, 1989.

Sugden, J., and A. Tomlinson, eds. FIFA and the Contest for World Football: Who Rules the Peoples' Game? Wiley, 1998. Cambridge, Polity Press.

Tänzler D K. Maras and A. Giannakopoulos, eds. The Social Construction of Corruption in Europe. Aldershot: Ashgate, 2012. 
Thompson, J.B. Political Scandal, Power and Visibility in the Media Age. Cambridge: Polity, 2000.

Tomlinson, A. The Men, the Myths and the Money. Global Institutions Series. London: Routledge, 2014.

Transparency International. Safe Hands: Building Integrity and Transparency at FIFA. Berlin: TI, 2011.

Transparency International. Transparency International Football Governance League Table. Berlin: TI, 2015.

Transparency International. Global Corruption Report: Sport. https://www.transparency.cz/ wp-content/uploads/Global-Corruption-Report-Sport-2016.pdf, 2016.

Uslaner, E.M. Corruption, Inequality, and the Rule of Law. Cambridge: Cambridge University Press, 2008.

Yallop, D. How They Stole the Game. London: Poetic Publishing, 1999. 